\title{
OBSCENITY AND THE FIRST AMENDMENT: THE SEARCH FOR AN ADEQUATE TEST
}

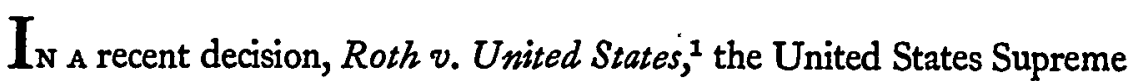

Court was confronted with the dilenima with which state and lower federal courts have long been struggling-namely, what is obscene, and to what extent may it be proscribed. Having declared that the area of constitutionally-protected speech does not encompass obscenity, ${ }^{2}$ the Court, nevertheless, indicated an awareness of the dangers inherent in such a broad rule and asserted that the standards for judging obscenity must, in order to withstand the charge of constitutional infirmity, ensure the protection of that material which is, in fact, bona fide in purpose, although it may, perhaps, tend to stimulate sexual thoughts. ${ }^{8} \mathrm{Mr}$. Justice Brennan, speaking for a majority of five, attempted to provide such a standard: "whether to the average person, applying contemporary community standards, the dominant theme of the material taken as a whole appeals to prurient interest."34

The judicial search for an adequate obscenity test began with the English case of Regina v. Hicklin, ${ }^{5}$ wherein Cockburn, C.J., declared:"

354 U.S. 476 (1957).

Id. at 485 . This assertion comes as no surprise, for as Justice Brennan notes, until this case the Supreme Court had always assumed that obscenity was not constitutionally protected. This assumption arose from dicta in Ex parte Jackson, 96 U.S. 727 ( 1877 ) where, while holding constitutional a federal statute prohibiting the use of the mails to advertise a lottery, the Court indicated by analogy that a Congressional act against depositing obscene matter in the mails was equally not in violation of the first amendment. Said the court, "In excluding various articles from the mail, the object of Congress has not been to interfere with the freedom of the press, or with any other rights of the people; but to refuse its facilities for the distribution of matter deemed injurious to the public morals." Id. at 736. Subsequent cases have likewise indicated that obscemity legislation is not unconstitutional. Beauharnais v. People, 343 U.S. 250, 255-257, 266 (1952); Winters v. People, 333 U.S. 507, 5to (1948); Hannegan v. Esquire, Inc., 327 U.S. 146, 158 (1946); Chaplinsky v. New Hampshire, 315 U.S. 568, $57^{1-572 ~(1942) ; ~ N e a r ~ v . ~ M i n n e s o t a, ~} 283$ U.S. 697, 716 (1931); United States v. Harmon, 45 Fed. 414, 415 (Kan. D.C. 1891); Unjted States v. Bennett, 24 Fed. Cas. No. 14,571, at 1095 (S.D.N.Y. 1879).

354 U.S. at 487 .

- Id. at 488.

2L.R. 3 Q.B. 360 (1868). This famous case involved the seizure (under 20 \& 21 VicT., c. 83 , s. I., The Obscene Publicatious Act of 1857) of a pamphlet entitled "The Confessional Unmasked" which, as a propaganda organ of the Protestant Electoral 
... the test of obscenity is . . whether the tendency . . . is to deprave and corrupt those whose minds are open to such immoral influences, and into whose hands a publication of this sort may fall.

Thus, it was determined that the objectionableness of literature was to be gauged by its effect on those most susceptible to prurience, on its possible rather than its probable audience. Nor were the author's intentions to have any relevance. ${ }^{7}$ Furthermore, because the court found that only portions of the publication involved were obscene, the case came also to stand for the proposition that the material need not be judged as a whole, but rather on the basis of isolated passages charged with being obscene. ${ }^{8}$

Union, was an attack on the Catholic Church. The court found that a magistrate's order that the pamphlet be destroyed was correct in that the pamphlet was obscene.

'Id. at 37 .

To defendant's contention that his motive was to prevent the spread and progress of the Roman Catholic Church and that his intentions were honest, Chief Justice Cockburn answered, "May you commit an offence against the law in order that thereby you may effect some ulferior object which you have in view, which may be an honest and even a laudable one? $M y$ answer is, emphatically no." Id. at 371-372. And Justice Blackburn of the same court stated, ". . although the appellant inay have had another object in view, he must be taken to have intended the natural consequence of his act. If he does an act which is illegal, it does not make it legal that he did it with some other object." Id. at 375 .

- In United States v. Bennett, 24 Fed. Cas. 1093, No. 14,57 I (S.D.N.Y. 1879), defendant's counsel was allowed to read and comment only on those portions of the material marked by the prosecution as falling within the indictment, althougb each member of the jury was provided with a copy of the book. In Commonwealth v. Friede, 271 Mass. 318,171 N.E. 472 (1930), the case notorious for declaring unfit Theodore Dreiser's Ant American Tragedy, the court refused to allow the entire book to be introduced into evidence and only sections chosen by the prosecutor were permitted. There, bowever, the court was laboring under a Massachusetts statute which forbade the sale of any book "containing" obscene language. In 1930 this statute was amended to bar the sale of obscene, indecent, or impure books, and Commonwealth v. Isenstadt, 318 Mass. 543,62 N.E.2d 840 (1945), although upholding a conviction for the sale of Strange Fruit, decreed that the book must be viewed as a whole in judging its obscenity.

Apparently the Hicklin test for obscenity is still applied in England. Regina v. Reiter [1954] 2 Q.B. I6 (C.A.); Regina v. Martin Secker \& Warburg, Ltd. [1954] I Weekly L.R. I138; Paget Publications, Ltd. v. Watson [1952] I All E.R. 1256 (Q.B.). And see Williams, Obscenity in Modern English Law, 20 Law \& Contemp. Prob. 630 (1955). In the Paget case the lower court found only the cover of the magazine, Slick Bedtime Stories, to be obscene, yet ordered 13,000 copies of the publication destroyed. On appeal, Lord Goddard, C.J., in affirming, declared: "It is not necessary to show that a publication is obscene on every page. A publication may be obscene because part of it is obscene." Paget Publieations, Ltd. v. Watson, supra at 
American courts soon adopted the Hicklin standard, ${ }^{9}$ but there were some misgivings. For instance, in United States v. Kennerley, ${ }^{10}$ Judge Learned Hand, although applying the Hicklin rule, felt that it was out of tune with the times and reduced the treatment of sex "to the standard of a child's library." . He argued that a modern test should take into consideration the "candor" a contemporary community was willing to accept and should be based on the "average conscience," rather than "the lowest, and least capable."11

It was not, however, until the famous Ulysses cases, ${ }^{12}$ some twenty years later, that the Hicklin rule was repudiated in this country. ${ }^{13}$

1257. In the Martin Secker case, Stable, J., charged the jury with the Hicklin standard, but directed them to consider it and apply it in the light of modern times. Regina v. Martin Secker \& Warburg, Ltd., supra. Concerning the English system, Judge Curtis Bok, in Commonwealth v. Gordon, 66 Pa. D. \& C. 101, 127-128 (r949), states:

The sule of Regina v. Hicklin suited the English, and presumably still does -not as a satisfying standard but as an effective policeman to take over and tone down the situation when the social experiment threatens to get out of hand.

Censorship should be the proper activity of the community rather than of the $1 \mathrm{aw}$, and the community has never been lazy upholding what it believes to be inherently decent at the moment. With a legal policeman handy, the market. . place is the best crucible in which to distil an instinctive morality. . . .

This is healthy, for it is the struggle of free opinion: it is not suppression by law. In the English community the people argue and Hicklin stands guard in case of trouble. The American method is different: the rule has been modernized.

- United States v. Bennett, 24 Fed. Cas. 1093, No. 14, 751 (S.D.N.Y. 1879); United States v. Smith, 45 Fed. 476 (E.D. Wis. 1891); Commonwealth v. Friede, 278 Mass. 318, 171 N.E. 472 (1930); People v. Muller, 96 N.Y. 408 (1884). See Rosen v. United States, 161 U.S. 29, 43 (1896), where the court approved the trial judge's instruction to the jury in terms practically identical with those used by Chief Justice Cockburn. The court added, "In view of the character of the paper . . . the test prescribed for the jury was quite as liberal as the defendant had any right to demand." Ibid.

${ }^{10} 209$ Fed. $\times 19$ (S.D.N.Y. $\left.\times 9 \times 3\right)$.

${ }^{11} I d$. at 121 .

18 United States v. One Book Entitled "Ulysses," 5 F. Supp. 182 (S.D.N.Y. 1933), aff'd, 72 F.2d 705 (2d Cir. 1934), involved the controversial novel by James Joyce. Upon its attempted importation into the United States, the customs collector, pursuant to Section $305(\mathrm{a})$ of the Tariff Act of 1930, 46 STAT. 688 (x930), 19 U.S.C. $\S 1305$ (a) (1952), seized the book and the United States attorney instituted proceedings for forfeiture.

${ }^{18}$ An earlier case, Halsey v. New York Society for the Suppression of Vice, 234 N.Y. I, 136 N.E. 219 . (1922) declared that the book involved should be considered as a whole. Also, in considering whether the book was ohscene, the court turned extensively to the views of critics. The case, however, dealt with the obscenity question 
There, the District Court for the Southern District of New York, holding the material in question not to be obscene, interjected the idea that the sincerity and artistry of the author should be considered and that the court must determine the effect of the entire book "on a person with average sex instincts-what the French would call l'homme moyen sensuel."14 On appeal, the Court of Appeals for the Second Circuit affirmed and set forth the new beacon for American courts: ${ }^{15}$

... the proper test ... is its dominant effect. In applying this test, relevancy of the objectionable parts to the theme, the established reputation of the work in the estimation of approved critics, if the book is modern, and the verdict of the past, if it is ancient, are persuasive pieces of evidence ...

As a result of these cases, therefore, literary and other social values of the work were to be taken into account, and no longer was the effect of isolated passages on those most susceptible to prurience to be controlling. Most of the subsequent American decisions have followed the Ulysses standard, ${ }^{16}$ although some courts still seemed to adhere to the Hicklin language. ${ }^{17}$

in an oblique fashion in as much as the court was concerned with an appeal from a judgment for the plaintiff in a malicious prosecution case.

${ }_{14} 5$ F. Supp. 182, 184 (S.D.N.Y. 1933).

${ }^{15} 72$ F.2d 705, 708 (2d Cir. 1934).

${ }^{16}$ Walker v. Popenoe, 149 F.2d $5 \times$ (D.C. Cir. 1945); Parmelee v. United States, 113 F.2d 729 (D.C. Cir. 1940); United States v. Levine, 83 F.2d 156 (2d Cir. 1936); New American Library of World Literature v. Allen, 114 F. Supp. 823 (N.D. Ohio 1953); Bantam Books, Inc. v. Melko, 25 N.J. Super. 292, 96 A.2d 47 (r953); People v. Gotham Book Mart, 158 Misc. 240, 285 N.Y. Supp. 563 (Mag. Ct. 1936); People v. Miller, 155 Misc, 446, 279 N.Y. Supp. 583 (Mag. Ct. 1935); State v. Lerner, 51 Ohio L.Abs. 32x, 81 N.E.2d 282 (C.P. 1948); Commonwealth v. Gordon, 66 Pa. D. \& C. ror (1949), aff'd sub, nom. Commonwealth v. Feigenbaum, i 66 Pa. Super. I20, 70 A.2d 389 (1950).

${ }^{17}$ Burstein v. United States, 178 F.2d 665 (9th Cir. 1949); United States v. Two Obscene Books, 99 F. Supp. 760 (N.D. Calif. 195x), aff'd sub nom. Besig v. United States, 208 F.2d 142 (9th Cir. 1953), these cases finding Henry Miller's Tropic of Cancer and Tropic of Capricorn obscene and unimportable under Section 305 of the 1930 Tariff Act, 46 STAT. 688 (1930), rg U.S.C. \$ r305 (1952); Hadley v. State, 205 Ark. 1027,172 S.W.2d 237 (1943); King v. Commonwealth, 313 Ky. 741, 233 S.W.2d 522 (1950).

For a more complete treatment of the development of obscenity law in the American courts, see Lockhart \& McClure, Literature, the Law of Obscenity, and the Constitution, 38 MinN. L. REv. 295 (1954), portions of which are recapitulated in Lockhart \& McClure, Obscenity in the Courts, 20 LAW \& CONTEMP. ProB. 587 (1955); Alpert, Judicial Censorship of Obscente Literature, 52 HARV. L. REv. 40 (1938). The following decisions also contain a more detailed analysis of the cases: Commonwealth v. 
In the Roth case, the Supreme Court concluded that the lower courts, in finding the material in question obscene, had "sufficiently followed the proper standard."128 But the majority opinion creates some confusion as to just what the standard is. Justice Brennan's articulation of the applicable test is replete with the language of the American Law Institute in its recent attempt to frame an obscenity test along more modern lines. ${ }^{19}$ In dissent, however, Justice Harlan noted that the Institute drafters expressly rejected the tests of "tendency to arouse lustful thoughts and desires" or "that which "tends to corrupt or debase," "these latter tests being precisely the ones applied in the lower courts and approved by Justice Brennan. ${ }^{20}$ This seeming inconsistency is perhaps clarified by Justice Brennan's footnote assertion that he perceives no important difference between the case law definition of obscenity and that proposed by the Institute. ${ }^{21}$ Thus, although he employs new language, he apparently reaffirms the old definition. ${ }^{22}$ This is unfortunate both in that it is confusing, and in that it fails to resolve certain problems that have arisen under the prevailing case-law standard.

Gordon, $66 \mathrm{~Pa}$. D. \& C. ror (r949) and Bantam Books, Inc. v. Melko, 25 N.J. Super, 292, 96 A.2d 47 (1953).

20 354 U.S. at $489-490$.

20 MOdel Penal CODE § 207.10 (Tentative Draft No. 6, 1957).

${ }^{20} 354$ U.S. at 499-500 (dissenting opinion); MODEL PENAL CODE $§ 20 \% .10$ (Tentative Draft No. 6, 1957) at 10.

$=22$ U.S. at 487 , footnote 20 , wherein it is stated, "We perceive no significant difference between the meaning of obscenity developed in the case law and the definition of the Model Penal Code. ..."

"2 Others have reached different conclusions. Three justices indicate their belief that the majority opinion adopted the American Law Institute formula, bnt they fail to provide any gronnds for their reasoning, save Justice Brennan's use of ALI language. 354 U.S. at 499-500 (Justice Harlan's dissenting opinion) and 513 (dissent of Justice Douglas, Justice Black concurring). Professor Louis B. Schwartz, Associate Reporter for the Model Penal Code, theorizes in a recent article that the majority opinion could have one of three, possible explanations: (a) the inajority favor the prevailing formulations and would construe any statate based on the Model Penal Code as not changing the present rule; (b) that Mr. Justice Brennan "disingenuously" used the Code to support the lower court instructions on obscenity; or (c) ". . . Mr. Justice Brennan may have been trying to bring existing law ap to the level of the Model Penal Code by the tour de force of declaring that it was already there." Professor Schwartz understandably prefers the latter hypothesis. Schwart, Criminal Obscenity Law, 29 PENN. B.A.Q. 8, 10-11 (1957). He later concludes, however, that for the purposes of its decision in Roth, the Supreme Court "does not espouse one or another of the available definitions but indicates a receptivity to the language of the Model Penal Code." Id. at 12-13. This conclusion is, perhaps, desirable, but it is hardly acceptable in the face of Mr. Justice Brennan's own words, note 20 supra, and in light of the fact that in support of his test Mr. Justice Brennan cites the Ulysses cases and those proceeding therefrom. 354 U.S. at 489 , footnote 26. 
A majority of the courts have, apparently, maintained the idea that the justification for enforcement of obscenity statutes is the protection of the public from literature that would likely "deprave and corrupt" through its tendency to arouse in the reader sexually impure thoughts. These opinions can be supported only in the light of the unproved assumption that such thoughts will lead to conduct that will contravene commonly accepted moral standards. ${ }^{2 \dot{3}}$ Thus, most recent critics who have attacked obscenity legislation and the decisions upholding it have employed the following rationale: There being no evidence that the reading of obscene literature leads to abnormal or immoral sexual behavior, ${ }^{24}$ the statutes, which are in derogation of constitutional guarantees, are, in reality, punishing literature and those who write, publish, sell, or distribute it for simply arousing impure thoughts. Some of the more astute judges, too, have adopted this viewpoint and, accordingly, seem disinclined to apply the sanctions authorized by obscenity statutes unless there is substantial proof that reading of the literature involved has led to or is about to lead to the commission of at least a misdemeanor. ${ }^{25}$ Were this approach generally to be followed, the practical

\footnotetext{
${ }^{28}$ See Lockhart \& McClure, Literature, The Law of Obscenity, and the Constitution, 38 MinN. L. REv. 295, 329-342, 373-387 (1954).

at See Mr. Justice Douglas's dissent, 354 U.S. at 508-514 and Judge Frank's concurring opinion in United States v. Roth, 237 F.2d 796, 811-818 (1956), wherein Judge Frank quotes from and discusses the conclusion of some recent studies on the effects of obscene writing on human behavior. "Also see Lockhart \& McClure; Literature, the Law of Obscenity, and the Constitution, 38 MINN. L. REv. 295, 382-387 (1945); Lockhart \& McClure, Obscenity in the Courts, 20 LAW \& Contemp. Prob. 587, 590-598 (1955); Alpert, supra note 18, at 73-75. But see, Schmidt, Justification of Statutes Barring Pornography from the Mail, 26 FordHAM L. REv. 7o (1957), which rather passionately attacks Judge Frank's opinion. Professor Schmidt argues: "If the reading of great books in the process of education, develops sound intellectual and moral habits which sooner or later will be, or tend to be, reflected in good character and conduct, it is a little difficult to understand why the reading of pornographic books and materials should be free from undesirable cultural and social effects proportionate to their occasion and influence." Id. at 74. His major thesis, however, is that so long as sociologists, psychologists, and other experts are in conflict as to the effect of obscene literature on human behavior, the courts should never consider an obscenity statute unconstitutional merely because the judges prefer the opinions of one group of experts over the other. Id. at 95. Professor Schmidt also notes that while the prevailing obscenity test properly concerns itself with effect on the ordinary adult, the legislature may be concerned, just as properly, with other groups in the commmunity, such as nonnormal adults and children; and, therefore, more consideration should be given legislative intent in enacting obscenity statutes. $I d$. at 83-88.

${ }^{28} \mathrm{Mr}$. Justice Douglas in his dissent in Roth states, "By these standards punishment is inflicted for thoughts provoked, not for overt acts nor anti-social conduct. This test cannot be squared with our decisions under the first amendment ... speech
} 
result would be nonenforcement of obscenity statutes, unless scientific evidence of causal connection between reading and acting could be adduced. Nevertheless, it is a telling argument, and the only answer would seem to be that the wealth of obscenity legislation ${ }^{26}$ at least indicates the presence of a social problem which the courts cannot totally ignore. ${ }^{27}$

Several authorities have suggested that the solution lies in less prosecution and a greater reliance upon public self-restraint. ${ }^{28}$ Their

to be punishable must have some relation to action which could be penalized by government." 354 U.S. at 509. And later in his opinion he adds, "Freedom of expression can be suppressed if, and to the extent that, it is so closely brigaded with illegal action as to be an inseparable part of it." Id. at 514. In Commonwealth v. Gordon, $66 \mathrm{~Pa}$. D. \& C. Ior (1949) aff'd sub nom. Commonwealth v. Feigenbaum, $166 \mathrm{~Pa}$. Super. 120, 70 A.2d 389 (1950), Judge Curtis Bok seems to accept the prevailing law as the proper test for obscenity, but then stipulates that the statute involved "may then be applied, as an exercise of the police power, only where there is reasonable and demonstrable canse to believe that a crime or misdemeanor has been committed or is about to be committed as the perceptible result of the publication or distribution of the writing in question: the opinion of anyone that a tendency thereto exists or that such a result is self-evident is insufficient and irrelevant. The causal connection between the book and the criminal behavior must appear beyond a reasonable doubt." Id. at 156. Judge Frank, likewise troubled by the constitutional questions raised by obscenity legislation and prosecution, states in his lengthly concurring opinion to United States v. Roth, 237 F.2d 796, 801-827 (2d, Cir. 1956), that he is inclined to agree with Judge Bok, although be would modify the application to situations where it could be shown that this type of book would probably produce anti-social conduct which by statute could be made a crime. Id. at 826 .

${ }^{38}$ The federal government and every state, except New Mexico, have statutes prohibiting obscene literature. Lockhart \& McClure, Literature, the Law of Obscenity, and the Constitution, 38 MinN. L. Rev. 295, 324 (1954). And New Mexico has a statute giving the various localities the powrer to enact obscenity laws. Model PeNal CODE $\S 207.10$ (Tentative Draft No. 6, 1957) at 5.

${ }^{27}$ See Alberts v. State of California, 354 U.S. 476 (1957), wherein Mr. Justice Harlan, concurring, states: "Clearly the state legislature has made the judgment that printed words can 'deprave or corrupt' the reader-that words can incite to anti-social or immoral action. The assumption seems to be that the distribution of certain types of literature will induce criminal or immoral sexual conduct. It is well known, of course, that the validity of this assumption is a matter of dispute among critics, sociologists, psychiatrists, and penologists. There is a large school of thought, particularly in the scientific community, which denies any causal connection between the reading of pornography and immorality, crime, or delinquency. Others disagree. Clearly it is not our function to decide this question. That function belongs to the state legislature." Id. at 501. See also United States v. Roth, 237 F.2d 796, 798-799 (2d Cir. 1956). Lockhart \& McClure, Obscenity in the Courts, 20 Law \& ConTEMP. Pros. 587, 596 (1955), concludes: "The courts can bardly be expected to withbold enforcement and application of obscenity laws to literature until some dependable scientific studies bave been made ... The courts bave the responsibility for giving some meaning and effect to this legislation, despite its lack of precision. . . ."

${ }^{28}$ See 354 U.S. 476, 514 (dissent by Mr. Justice Douglas); 237 F.2d 796, 823 (2d 
argument is that this approach avoids the difficulties and dangers present in any attempt to frame and enforce an acceptable standard in this field. There are grave doubts, though, that private censorship and action, with all of its vigilante connotations, would be a fairer or more satisfactory method than the one now utilized, which at least grants an open judicial hearing. ${ }^{2 \theta}$

Perhaps the best approach would be the formulation of an obscenity standard which would encompass, if not in definition, at least in application, the more astute analyses of judges and scholars, and which would, at the same time harmonize the traditionally high value placed on the freedom of expression, thus preserving for legislatures the broad policy decision as to the need for prohibitions against obscenity. ${ }^{80}$ Indeed, this may be the only approach possible now that the Roth decision has made many of the constitutional arguments somewhat academic.

The American Law Institute sets forth this formula for the determination of obscenity: $:^{31}$

A thing is obscene if, considered as a whole, its predominant appeal is to prurient interest, i.e., a shameful or morbid interest in nudity, sex, or excretion, and if its goes substantially beyond customary limits of candor in description or representation of such matters ... Obscenity shall be judged with reference to ordinary adults. ...

Cir. 2956) (Judge Frank's concurring opinion); and Judge Bok's notions, note to supra. See also Alpert, supra note 17 , at 73-76.

"The authorities who argue for public self restraint, note 28 supra, probably conceive a system whereby people exercise individual and independent judgments as to what they shall read. Assuming this to be so, the idea of self-restraint is appealing. The trouble lies in the fact that invariably people of like minds band together to inflict their standards and judgments upon the entire community through pressure, blacklists, and boycotts. Often such extra-legal methods prevent the coinmunity from knowing what material it is not having an opportunity to read. See Lockhart \& McClure, Literature, the Law of Obscenity, and the Constitution, 38 MINN. L. Rev. 295, 302-320 (1954) for an insight into some of the inethods employed by various existing citizen groups in this field. The abolishment of obscenity legislation might well be taken as a tacit encouragement of such private censorship methods, a system far more abhorrent than that exercised by the courts. Id. at 309; MODEL PENAL CODE $\S 207.10$ (Tentative Draft No. 6, 1957) at 9.

${ }^{30}$ See notes 26 and 27 supra.

"2 Model Penal Code $\$ 207.10$ (Tentative Draft No. 6, 1957) at I. The drafters also provide that if the material appears to be designed for children or some other "specially susceptible" audience, it shall be judged with reference to that special group. $I d$. at $\mathrm{x}-2$. And see the cominent, id. at 10 , and the further discussion of the prevailing tests of effect on the reader and the proposed test of ALI, id. at I9-40. 
To prove these elements, the Institute would allow evidence tending to show: (a) the character of the audience to which the material is directed; (b) the appeal of the material and its effect, if any, on behavior; (c) the artistic, literary, scientific, educational or other merits of the work; (d) the degree of public acceptance; (e) the appeal to prurient interest or absence thereof in the advertisement of the material; and, perhaps, (f) the purpose and reputation of the author, publisher and disseminator. Expert testimony and testimony from author or publisher are expressly permitted ${ }^{32}$ In addition, the drafters suggest that while the jury should not be abolished in this field, the trial judge should be given more freedom to determine the obscenity of the material for himself, and appellate courts should be permitted to make independent judgments as to the obscenity of the material..$^{38}$

The Institute states that its definition differs from existing case law in that it directs its attention "to qualities of the material itself; the capacity to attract individuals eager for a forbidden look," rather than to the effect of a book upon a reader's thoughts. ${ }^{34}$ But the distinction here inay exist not in definition, but in application; for how is one to judge the obscene quality of the material without determining its effect upon thoughts? The Institute assumes that many environmental factors, including the opposite sex, are likely to arouse or stir lustful thoughts and desires and that it is impossible to suppress such thoughts, regardless of the statutes or tests employed. ${ }^{35}$ Therefore, it is the

"2 Id. at 2, 43-46.

${ }^{22}$ Id. at 2-3. The Code would permit the trial judge to acquit if he believes the material not obscene even if the evidence is such that reasonable men could differ. The trial judge may seek the advice of psychiatrists, sociologists, and critics in making his independent judgment. Both defendant-and prosecution may appeal the trial judge's decision as to obscenity. The provision for de novo appellate review is principally to prevent local pressures from unjustifiably causing convictions. Id. at 46-49. Actually, this proposal was defeated by a small margin of votes at the May 1957 meeting of the Institute, but the Reporter will apparently redraft it in an attempt to meet objections without changing the principle of more judicial responsibility in this area. Schwartz; supra note 22, at 15 .

"4 Model Penal CODE $\$$ 207.xo (Tentative Draft No. 6, 1957) at 10.

ss "As an independent goal of penal legislation, repression of sexual thoughts and desires is hard to support. Thoughts and desires not manifested in overt antisocial behavior are generally regarded as the exclusive concern of the individual and his spiritual advisors. It is not even clear that complete suppression of pornography would substantially affect the rate of erotic response in the population. Some believe that obscenity is largely a subjective experience so that individnals inclined in this direction will derive sexual stimulation from whatever is available, especially in a society like onrs in which the female figure is commonly employed by advertisers to evoke interest, where perfumes and textures are widely touted for erotic effect, and where the pervasive theme of mass 
avowed intention of the Institute to reach principally the commercial "panderer" of literature calculated and designed to appeal to prurient interest. $^{36}$ In this sense, the ALI standard is decidedly different from the case law, for it focuses its attention on the method and conduct of the "panderer" in creating and providing questionable material for public consumption and strives to punish him for this conduct. ${ }^{37}$ But when the question is raised as to the justification for punishment of these persons, one is led to conclude that their conduct is considered reprehensible only for the reason that they are disseminating material which has a tendency to arouse lustful thoughts and that this is, assumptively, injurious to the community. It may be, therefore, that while the ALI proposal offers little that is new for an abstract definition of obscenity, it does limit the application of obscenity statutes to a more definite class of persons, type of conduct, and kind of literature. In this sense, perhaps, it less offends constitutional sensibilities by providing greater protection for that which is legitimate but might have a tendency to arouse lustful thoughts.

Of greater significance than the matter of definition, then, is the attempt by the Institute to specify the nature of the evidence which should be admissible in the determination of what is obscene. In this regard, the Institute's effort accords closely with other recent attempts to reform obscenity legislation. ${ }^{38}$ Needless to say, much of what the

theater, literature and music is an eroticism that is obvious even while it fails to transgress the strictest obscenity law that could be envisioned." Id. at 20 . See also Alpert, supra note 17 , at 73 , where it is noted that of 409 college women who were asked what things they found most stimulating, '9 said 'Music,' 18 said 'Pictures,' 29 said 'Dancing,' 40 said 'Drama,' 95 said 'Books,' and 218 noted very simply 'Man."

${ }^{80}$ MOdel Penal CODE $\$ 207.10$ (Tentative Draft No. 6, 1957) at 13-15. The Code specifically excludes as criminal offenses dissemination to edueational institutions or scientists having special reason to possess such material. Id. at 3, 16-17.

${ }^{87}$ Mr. Chief Justice Warren's approach, in his brief concurring opinion in Roth, is similar. 354 U.S. at $494-496$.

${ }^{88}$ See Society of Authors Draft Bill, A Bill to Amend and Consolidate the Law Relating to Obscene Publications, House of Commons Bill 56 (1955), a revised and shorter version of which was debated in the House of Commons in the spring of 1957 and subsequently referred to committee; New Zealand Indecent Publications Act, 1910, as amended, $\S 5,2$ N.Z. PUB. ACTS 346 (1910), 2 N.Z. STAT. II71 (1954). The English proposal and the New Zealand statute are set forth in Model PeNAL CODE \$ 207.10 (Tentative Draft No. 6, 1957), Appendix 88-95. See also Williams, Obscenity in Modern English Laq, 20 LAW \& Contemp. ProB. 630, 644-646 (1955).

In June 1957, the North Carolina General Assembly enacted a bill embodying the provisions of the MODEL PENAL CODE, $\S 207.10$, but at the same time retaining, at least temporarily, the existing North Carolina statute relating to obscene literature. 
Institute and others propose is not new. Some courts have permitted expert testimony and other evidence of the type described by the Institute, and some judges undoubtedly give consideration to many of the questions upon which such evidence would tend to shed light.90 But the suggestion here is that it would be better if, in the future, courts gave more attention to clarifying not only tests and definitions for obscenity, but also evidence that is to be admitted and the considerations that are to be weighed in prosecutions for obscenity. Perhaps in this manner the necessarily broad tests can be sufficiently limited in their application to maintain enforcement of obscenity statutes without infringement upon that most precious right, freedom of expression.

Schwartz, supra note 22, at 13 . And see N.C. Sess. Laws 1957, c. 1227 and N.C. GEN. STAT. \& 14-1 89 (Supp. 1955).

${ }^{80}$ Lockhart \& McClure, Literature, the Law of Obscenity, and the Constitution, 38 MinN. L. REv. 295, 341-350 (1954). 